\title{
RESEARCH PROJECTS IN RESIDENTIAL TECHNOLOGY
}

MARCH 1992

Bonneville Power Administration Office of Energy Resources Residential Technology Section

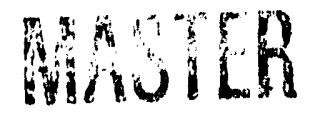




\section{TABLE OF CONTENTS}

INTRODUCTION 1

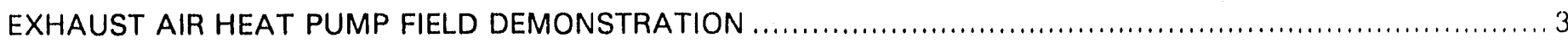

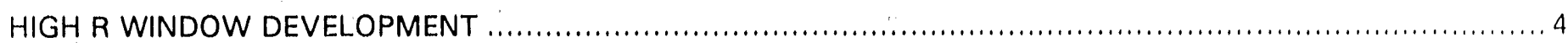

JAPANESE REFRIGERATORS: A FIELD PERFORMANCE ANALYSIS FINAL REPORT ............................. 5

MANUFACTURED HOMES THERMAL ANALYSIS AND COST EFFECTIVENESS REPORT $\ldots \ldots \ldots \ldots \ldots \ldots \ldots \ldots \ldots$

DEALER PARTICIPATION IN BPA'S MANUFACTURED HOUSING RESIDENTIAL CONSTRUCTION

DEMONSTRATION PROJECT. 7

AIR-LEAKAGE TESTS OF MANUFACTURED HOUSING IN THE NORTHWEST USA $\ldots \ldots \ldots \ldots \ldots \ldots \ldots \ldots \ldots \ldots . \ldots$

INVESTIGATION OF FOAM-CORE MATERIALS IN THE CONSTRUCTION OF MANUFACTURED HOMES ..........9

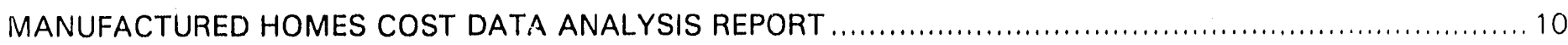

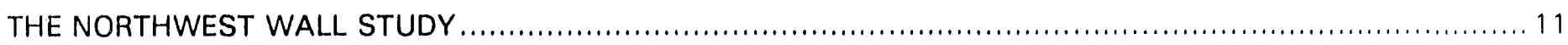

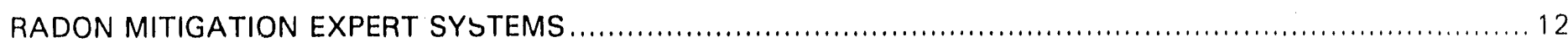

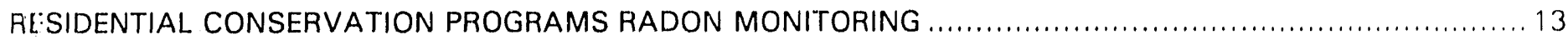

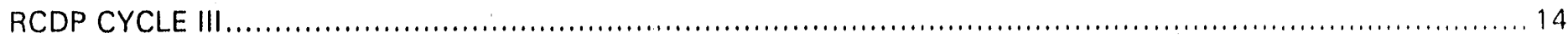

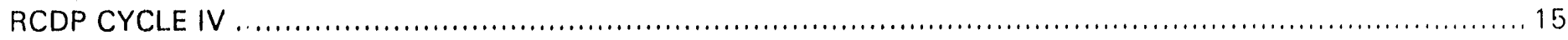

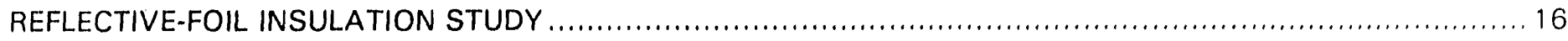

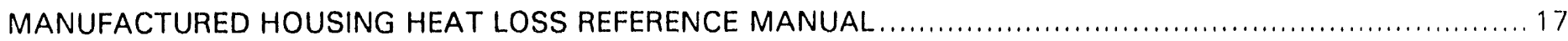

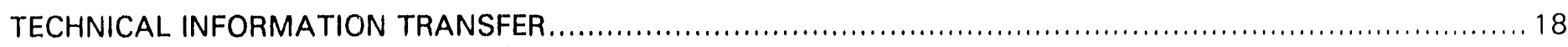

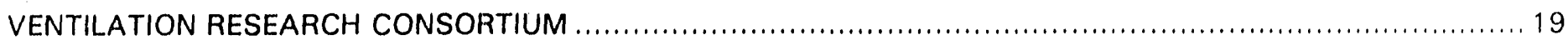

INFLUENCE OF SUBSLAB AGGREGATE PERMEABILITY ON SUBSLAB VENTILATION PERFORMANCE ............20

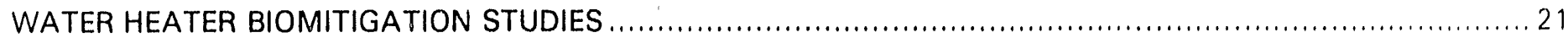

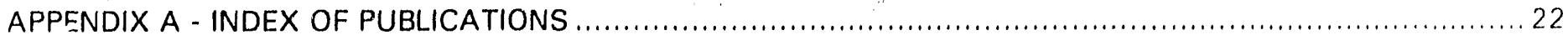




\section{ABBREVIATIONS DEFINED}

$\begin{array}{ll}\text { BPA } & \text { Bonneville Power Administration } \\ \text { RCDP } & \text { Residential Construction Demonstration Project } \\ \text { SGC } & \text { Super Good Cents } \\ \text { HUD } & \text { Housing \& Urban Development } \\ \text { WSEO } & \text { Washington State Energy Office } \\ \text { DOE } & \text { Department of Energy } \\ \text { ORNL } & \text { Oak Ridge National Laboratory } \\ \text { MCS } & \text { The Model Conservation Standards } \\ \text { EPRI } & \text { Electric Power Research Institute } \\ \text { LBL } & \text { Lawrence Berkeley Laboratory } \\ \text { EAHP } & \text { Exhaust Air Heat Pump }\end{array}$




\section{INTYODDCTION}

This document reports the energy efficiency technology research, development and demonstration (RD\&D) activities in the residential sector at the Bonneville Power Administration (BPA). It provides a brief description of recently completed and ongoing projects sponsored by the Residential Technology Section at BPA. On each project's one page summary, the project's objectives, study approach and results thereof, are presented. Where reports or other publications are available, that information is also supplied. Last but not least, the contact person for each project, usually the project manager, is listed.

A complete listing of available publications from previously completed projects is included in Appendix A.

Reports with a document number (DOE/BP $x x x x x$ ) can be obtained by calling the Residential Technology Section at (503) 230-5488. For publications without a document number, or any information pertaining to specific projects, please contact the person(s) listed on the project summary sheets.

\section{WHO ARE WE and WHAT DO WE DO}

The Residential Technology Section is one of three organizational entities of the Residential Programs Branch, in the Division of Resource Management. The Section sponsors research, development and demonstration projects in residntial energy efficiency technologies, and to facilitate the transfer of such technologies to the end users. We evaluate various energy conservation measures' (ECM) performance, reliability, availability, and cost effectiveness, and to incorporate appropriate measures into conservation resource acquisition programs, working in concert with Headquarters and Area Offices staff.

The Section sponsors a large number of projects, many of which span over several years. In general, the RD\&D projects fall into one of the following broad categories:

-- Building Evelope Efficiency

-- Space Conditioning Systems

-- Lighting and Appliances

-- Indoor Environment 


\section{HOW and HOW MUCH}

Most of the RD\&D work are performed through contracting with outside organizations, although occasionally BPA's laboratories and technical resources are also used. Contractors include all four State Energy Offices; utilities; manufacturers; engineering and consulting firms; universities and university extension services; National Laboratories; and the Electric Power Research Insitute.

We actively seek collaborative and co-funding opportunities with our utility customers and other potential project contractors. For example, we have several projects with EPRI under co-funding and "Tailored Collaboration" agreements. We have also been successful in negotiating co-funding arrangements with utilities and national laboratories.

The annual residential technology RD\&D expenditure is about $\$ 2$ million.

\section{FOR MORE INFORMATION}

For more information, please contact the project managers indicated on the project summary sheets. You may also contact:

Louis Y. Lee, P.E.

Chief, Residential Technologies

Bonneville Power Administration

P.O. Box $3621 \mathrm{M} / \mathrm{S}$ RMRD

Portland, OR 97208-3621

Phone (503) 230-3082

FAX (503) 230-4973 


\section{EXHAUST AIR HEAT PUMP FIELD \\ DEMONSTRATION}

This project will collect cost and performance data on 40 exhaust air heat pumps (EAHP). Twenty of these are in northern Idaho, and twenty are in the puget sound area. EAHP extract the latent and sensible heat from air exhausted from the house and return the heat to the house in the form of hot water.

\section{Objective}

In houses that are well insulated, the amount of energy used to heat water can exceed the space heating energy use. The only way to reduce water heating energy use is to reduce that amount of hot water consumed within the house, or improve the efficiency of the water heating system. Laboratory and limited field testing have indicated that EAHP are a viable technology to improve water heating efficiency. This project will obtain cost and performance data which will be used to better define the conservation resource available from EAHP.

\section{Key Findings:}

New Project

\section{Publications:}

None Available at this time.

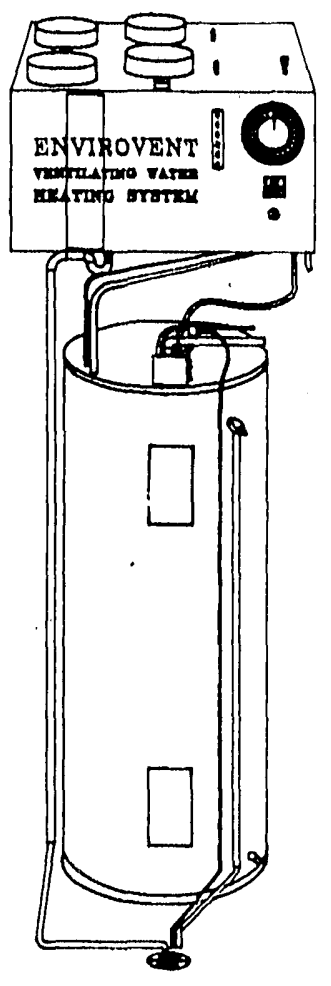

Status:

Several builders and home occupants have been recruited for the project. and a contractor has been selected to install monitoring equipment. Data from the first few sites should be available in early 1992.

Project Manager:

Mark Jackson

(503) 230-5475 


\section{HIGH R WINDOW DEVELOPMENT}

Several projects involving improvements to window efficiency have been funded by BPA. These projects range from computer modelling of various frame and glazing improvements, to monitoring prototype superwindows installed in cold climates.

\section{Objective:}

To develop and evaluate highly efficient windows, and to make the technology required to produce these windows available to manufacturers.

\section{Ker Findings:}

It is possible to substantially reduce the heat loss of both wood and vinyl framed windows.

Improved High-R windows, which have a heat loss coefficient (U-factor) of less than 0.20 , are twice as efficient as the best low emmisivity (Low-E) double glazed window. Vinyl window frames can be theimally improved by filling the cavities in the frame with insulating foam or shredded mylar. Edge of frame heat loss can be reduced by using insulating foam spacer strips between the panes of glass, and suspended Low-E films with krypton gas fill can reduce center of glass heat loss.

Publications:

High-R Window Research

DOE/BP-1017

\section{Other Reference Materials:}

In-Site Measurement of U-values and Overall Thermal Performance of Windows

DOE/BP-64357-1

A Superwindow Field Demonstration Program in Northwest Montana

LBL-26069

\section{Status:}

A full report assessing the field performance of superwindows should be available in early 1992. A guidebook for manufacturers will be completed in late 1991.

\section{Contractors Involved:}

Lawrence Berkeley Laboratory - Dariush Aresteh

\section{Project Manager:}

Mark Jackson

(503) 230-5475

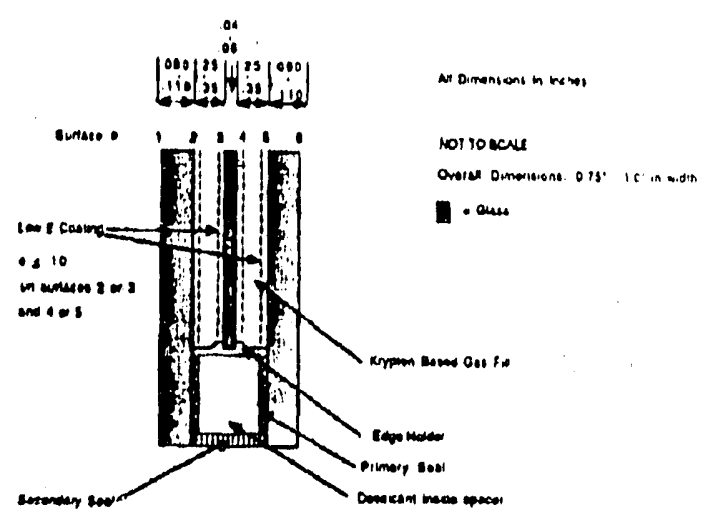

Croes section of CLL superwincow. 


\section{IAPANESE REFRIGERATORS: A FIELD PERFORMANCE ANALYSIS FINAL REPORT}

A test of in home energy use of 12 Japanese refrigerators over a testing period of 16 months.

\section{Objective:}

To compare actual in home energy use of Japanese refrigerators, to the energy use predicted by the U.S. DOE and Japanese laboratory test standards.

\section{Key Findirıgs:}

Japanese refrigerators use about 43 percent more energy with the U.S. DOE laboratory test than with the Japanese laboratory test.

\section{linergy Use fistimations for Japanese Refrigerators}

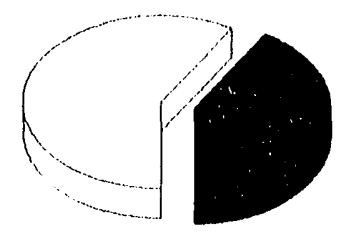

$$
\text { G US DOF' lab Tresi Japanese Lab Tesl }
$$

In the Portland/Vancouver area, the in-home energy use for Japanese refrigerators without antisweat switches was 15 percent higher than predicted by the Japanese test procedure and 25 percent lower than DOE test procedures. The refrigerators with anti-sweat switches used 2 to 13 percent more energy than predicted by the DOE test.
There was a relatively high correlation of energy use with outside temperature. The highest monthly energy use occurred in July and August and the peak weekly energy use often occurred during these months. This suggests refrigerator energy use is sensitive to kitchen temperatures.

\section{Publication:}

Japanese Refrigerators: A Field Performance

Analysis Final Report

DOE/BP-95951-2

February 1990

\section{Other Reference Materials}

Field Perfurmance of an Energy Efficient

Refrigerator Over 29 Months.

DOE/BP 1115

Energy Use Test Procedures for Appliances - Case Study of Japanese Refrigerators.

DOE/BP-63585-1

\section{Contractors Involved:}

Lambert Engineering

\section{Project Manager:}

Roy Reinhart

(503) 230-5491 


\section{MANUFACTURED HOMES THERMAL ANALYSIS AND COST EFFECTIVENESS REPORT}

The metered space-heating energy of 150 HUDcode manufactured homes built to Super Good Cents (SGC) standards and installed under the Residential Construction Demonstration Project (RCDP) and the manufacturer's incremental costs of the SGC requirements over most common industry practice were analyzed.

\section{Objective:}

To evaluate the energy savings and cost effectiveness of building HUD-code manufactured homes to SGC standards instead of building to the most common practice on manufacturers in thie Pacific Northwest.

A second objective was to evaluate a computer model used to predict the savings of building to SGC standards.

Status:

Completed

\section{Key Findings:}

The costs and associated savings for incremental increases in component insulation were calculated to determine the highest levels of component thermal efficiency that were cost effective for the region.

This information was used to determine the component thermal efficiency requirements for the new region-wide SGC program for HUD-code manufactured homes.

Publication:

Manufactured Homes Thermal Analysis and Cost Effectiveness Report

DOE/BP-35738-4

Contractors Involved:

Ecotope

Project Manager:

Steve Onisko

(503)230-5490

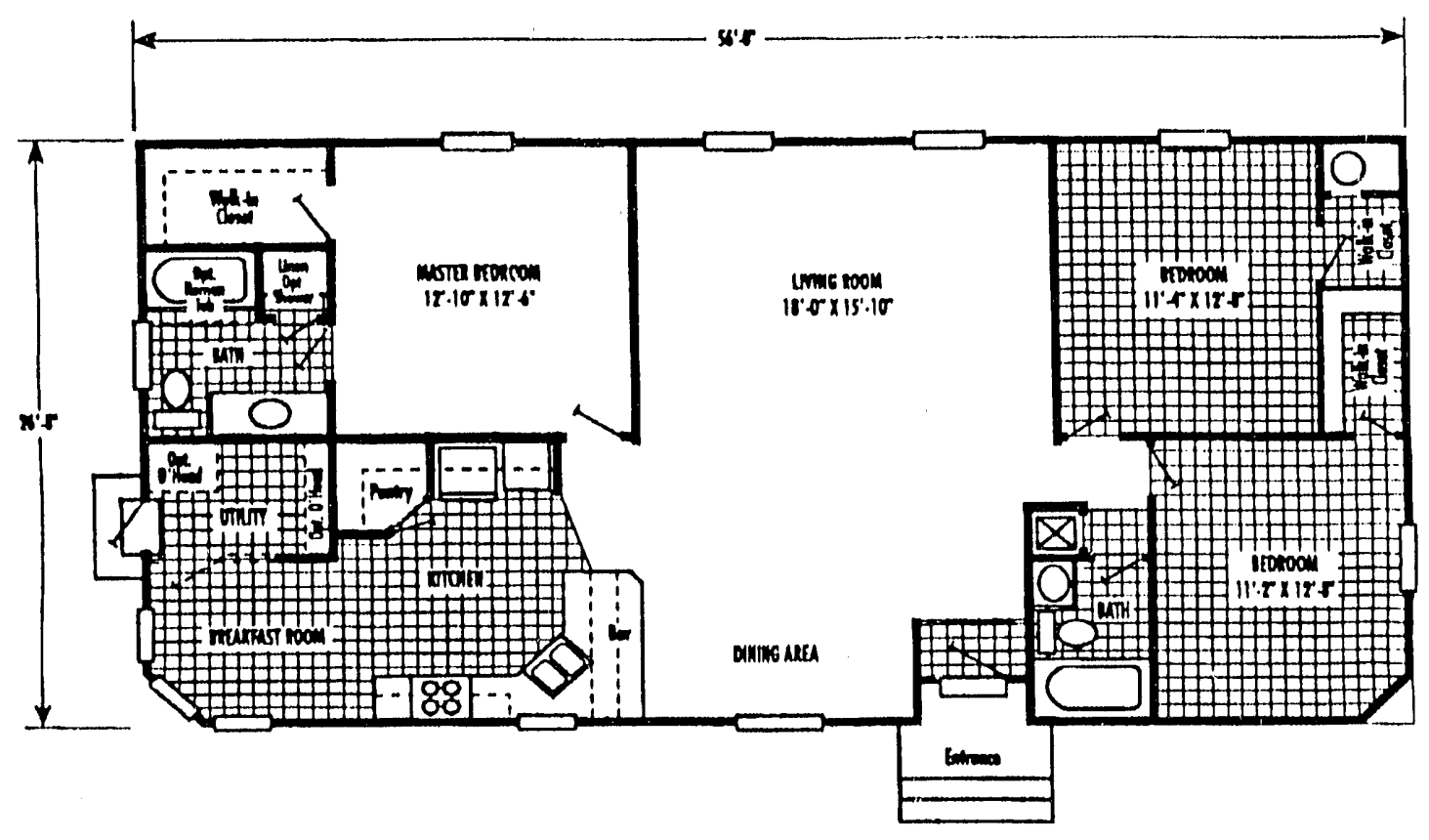




\section{DEALER PARTICIPATION IN BPA'S MANUFACTORED HOUSING RESIDENTIAL CONSTRUCTION DEMONSTRATION PROIECT.}

A total of 150 HUD-code manufactured homes meeting the Super Good Cents (SGC) standards were sited under the Residential Construction Demonstration Program, with participation by eight manufacturers and 40 dealers.

\section{Objective:}

To interview the participating dealers and elicit their impressions on marketing and setting up SGC mianufactured homes and their overall experience with the program.

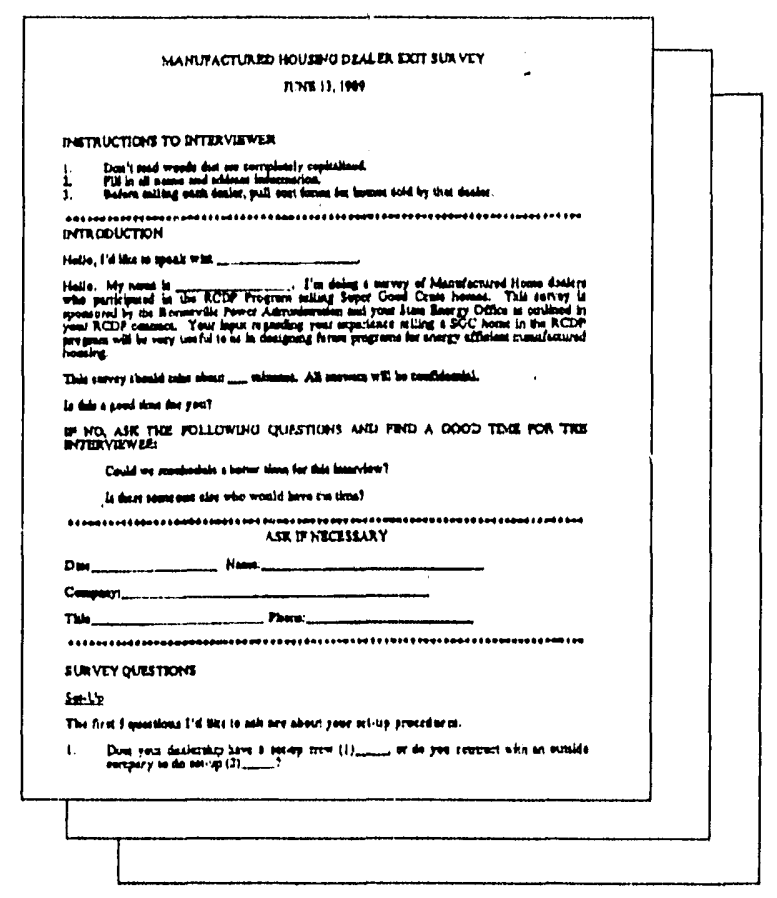

Key Findings:

None of the dealers reported that SGC homes were "very difficult" to sell and there was remarkably even distribution of those reporting the homes as "very easy", "somewhat easy", and "somewhat difficult" to sell.

Dealers who reported SGC homes as "somewhat difficult" to sell felt that the higher price and fewer windows were the main reasons. Dealers who reported SGC homes as easy to sell credited the benefits of lower utility bills, high quality, and media advertising as the main reason.

Publication:

Dealer Participation in BPA's Manufactured Housing Residential Construction Demonstration Project.

DOE/BP-1324 Jan 1990

Status:

Completed

Contractors Involved:

Washington State Energy Office

Project Manager:

Steve Onisko

(503) 230-5490 


\section{AIR-LEAKAGE TESTS OF MANUFACTURED HOUSING IN THE NORTHWEST USA}

HUD-code Manufactured housing represents nearly one half of the electrically-heated, single-family housing stock currently being installed in the Pacific Northwest. The air infiltration rate for these homes, and the potential energy savings that could be achieved by better air sealing, were unknown.

\section{Objective:}

To establish a data base for air leakage for manufacturing and installation practices and to estimate the energy savings potential and the cost effectiveness of additional on-site air sealing.

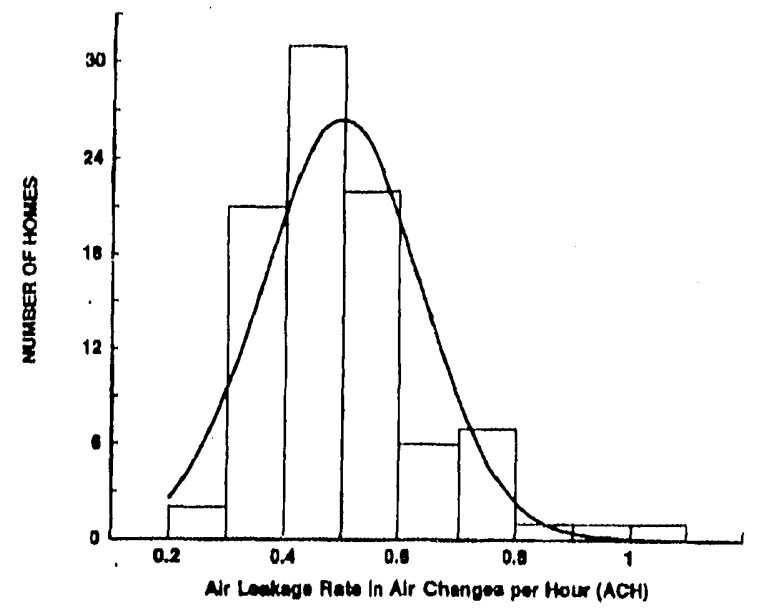

\section{Key Findings:}

The study found current practice manufactured homes had moderately lower air leakage rates than homes built on-site. Major leaks occurred at the marriage line where the two halves of the home joined, and in the link between the furnace on one side of the home and heating ducts on the opposite side. Leaks were also found at plumbing holes, around electrical panels, and in gaps around showers and bathtubs. Though windows leaked, no statistical correlation was found between the amount of glass in a house and overall leakage rates.
Doctoring the leakage areas with caulk, tape, gaskets and foam reduced air leakage about 20 percent and cost approximately $\$ 200$ per house.

\section{Publication:}

Paper - Air Leakage tests of manufactured housing in the Northwest.

Authors: Calvin W. Ek, Steven A. Onisko, and George O. Gregg.

\section{Status:}

Complete.

\section{Project Manager:}

Steve Onisko

(503) $230-5490$ 


\section{INVESTIGATION OF FOAM-CORE MATERIALS IN THE CONSTRUCTION OF MANUFACTURED HOMES}

Investigation on the use of foam-core materials in the construction of Manufactured Housing.

\section{Objective:}

The use of foam-core materials is finding wider acceptance in the construction of new homes. Significant advantages could be realized in the application of this material in manufactured housing. Bonneville is in a unique position to investigate the application of foam-core materials. Its present success and rapport with the manufactured housing industry in building energy efficient homes allows the opportunity for the application of a new material in these homes.

\section{Key Findings:}

There will be cost and energy savings in the application of foam-core in manufactured housing. Any barriers to its application, such as codes, fire and safety, will be investigated.

\section{Publication:}

Not available at this time.

\section{Status:}

The project has not yet begun. Completion of the project is expected to be one year from the startup date.
Contractors Involved:

DOE--Building Systems and Materials Division.

Project Manager:

S.A. Onikso

(503) 230-5490. 


\section{MANUFACTURED HOMES COST DATA ANALYSIS REPORT}

Manufacturers recorded their costs for building 150 HUD-code manufactured homes to the Super Good Cents (SGC) standards for the Residential Construction Demonstration Project.

\section{Objective:}

To determine the incremental costs for each component to build HIJD-code manufśctured homes to the SGC standards instead of building to the most common practice of Pacific Northwest Manufacturers.

\section{Key Findings:}

The materials cost, wholesale price, retail price, and the manufacturers' mark-ups were determined for each component in the thermal envelope.

The combined impact of the manufacturers' buying policies, material stocking, and volume purchasing could reduce the incremental costs for a regionwide program. This applies to virtually all measures, but is especially true for windows.

\section{Publication:}

Manufactured Homes Cost Data Analysis Report.

DOE/BP-35738-1 April 1990

\section{Status:}

Completed

Contractors Involved:

Ecotope

Washington State Energy Office

\section{Project Manager:}

Steve Onisko

(503)230-5490 


\section{THE NORTHWEST WALL STUDY}

A field study to examine energy efficient homes in the Pacific Northwest for excessive moisture and moisture related damage in walls.

\section{Objective:}

To determine if moisture is present in the exterior walls of newly constructed homes in the Northwest; to reduce moisture to acceptable levels; and to obtain information on measures needed to achieve this goal.

\section{Key Findings:}

In Phase I of the study, more than half of the newly constructed homes in the Northwest nad moisture accumulations in the walls. This moisture does not appear to be linked to the construction of the homes. Instead, the likely causes are failure of ventilation equipment and failure of occupants to use the equipment to control humidity inside the home.

In Phase II, homes with high wall moisture were retested in the summer to determine if the problem is seasonal or occurs year-round. In homes with continuously high wall moisture, mitigation measures were installed. The following winter, these homes were retested to determine the effectiveness of the mitigation measures.

In the final phase, phase III, the sixteen homes that still had wet walls were reopened. Moistu e mitigation rneasures were installed and the homes were openod again to check the effectiveness of the mitigation.

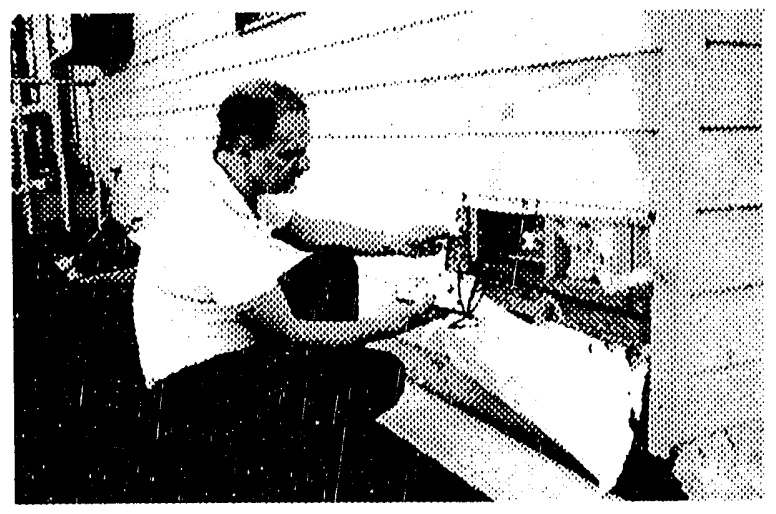

Most of the causes of moisture problems in walls can be divided int three general categories: 1) moisture entering walls from the inside of the house, 2) moisture entering walls from outside the house, and 3) high outdoor relative humidities in costal regions. This report contains recommendations for builders and contractors, building code officials, and hume occupants which should greatly reduce high wall-moisture levels in both current-practice and energy-efficient homes.

\section{Publication:}

The Northwest wall study: A field study of excess moisture in walls and moisture problems and dampness in new Northwest homes. DOE/BP-9/489-1

\section{Other Reference Materials}

Prediction of Moisture in Walls of Residences. DOE/BP-64355-1

The Spokane Wall Insulation Project: A Field Study of Moisture Damage in Walls Insulated Without a Vapor Barrier.

Contractors Involved: George Tsongas, PSU.

Project Manager:

Roy Reinhart

(503) 230-5491 


\section{RADON MITIGATION EXPERT SYSTEMS}

Develop a computer expert system to assist radon mitigators in the selection arid design of residential radon mitigation systems.

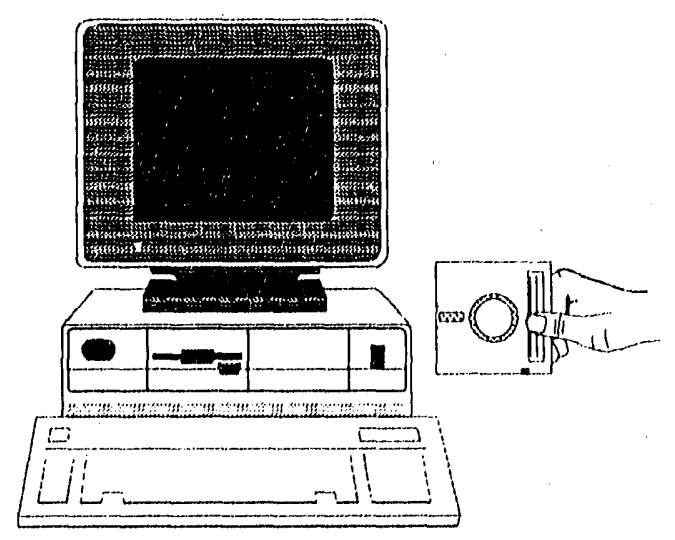

\section{Objective:}

To enharice the ability of regional agencies to address indoor radon problems.

\section{Key Findings:}

Demonsiration of the Software at conferences has generated much interest and provided valuable input.

\section{Status:}

Presently distributing software for review by experienced mitigators. Final product to be available in August, 1992.

\section{Contractors Involved:}

Dr. Pah Chen, Portland State University.

\section{Project Manager:}

Charles Eastwood

(503) 230-4992 


\section{RESIDENTIAL CONSERVATION PROGRAMS RADON MONITORING}

All homeowners that are participating in tho BPA Conservation programs are provided the opportunity for free radon monitoring.

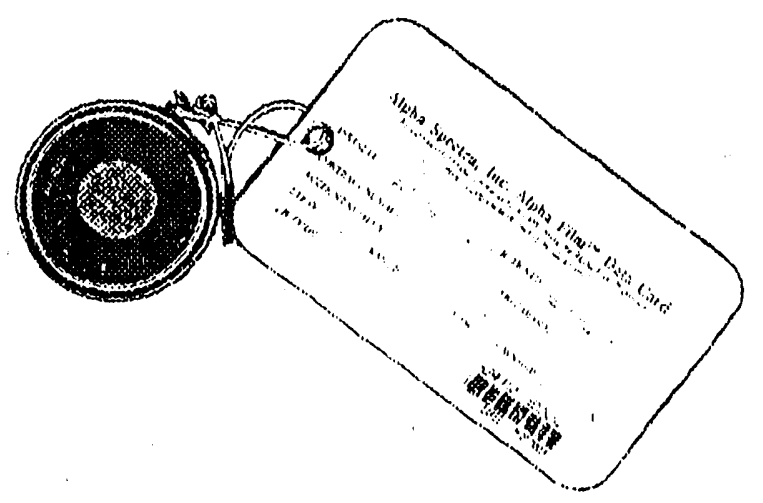

Objective:

To provide the homeowner the best information regarding their indoor radon levels.

\section{Key Findings:}

As of January 1991, BPA had monitored more than 40,000 homes in the Northwest. Of these homes, 4.92 percent had levels exceeding the U.S. EPA's indoor radon guideline, and 3.40 percent had levels exceeding BPA's action level-of $5 \mathrm{pCi} / \mathrm{l}$, the level at which BPA will provide mitigation assistance to homes in its weatherization program.

BPA publishes an annual report which includes a map and data listing of the updated radon monitoring results.
Publication:

Radon Monitoring Results from BPA's Residential Conservation Programs.

\section{Status:}

Monitoring ongoing

Contractors Involved:

Frank Wilkinson, III

Alpha Spectra, Inc..

Project Manager:

Charles Eastwood

(503) 230-4992 


\section{RCDP CYCLE III}

RCDP Cycle III consists of four projects: 1) Sir.gle Family Ventilation Case Studies is an assessment of existing information and field evaluations of ventilation systems in existing SGC/NWEC homes. Field evaluations examined things that effect ventilation system performance such as inlet veints, bath exhaust fans, automatic controls, ocisupant habits, etc., 2) Multifamily Ventilation Systems constructed and gathered performance data on five to six innovative multifamily ventilation systems. Developers were recruited to build matched pairs so that comparisons can be made between innovative ventilation systems, and conventional SGC ventilation systems. 3! l.og home Demonstration is an investigation to assess the thermal performance of log homes, and 4) Single Family Heating Systems an investigation focusing on heat pump performance through case study investigation.

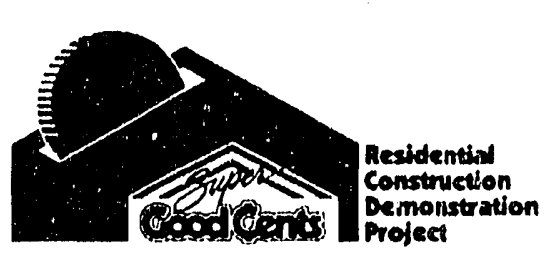

\section{Objective:}

1) Single familv ventilation case studies investigation documents experience that can be transfered to utilities builders, HVAC contractors, etc. on what works and does not work with regard to design, installation, and operation of ventilation systems in existing SGC/NWEC homes.

2) Multifamily ventilation systems studies the performance of alternative ventilation systems that meet the intent of SGC for multifamily buildings.

3) Log home Demonstration tcollects and documents information on the thermal performance and infiltration levels of log homes built to improved energy efficiency levels

4) Single Family Heating Systems to estimate overall heating system efficiencies in homes with electric furnaces and heat pumps, since the magnitudes and ranges of variation of these efficiencies are currently unknown. A secondary goal is to develop the package of test equipment, procedures and measurement protocols which could be applied in the future to a larger sample of homes.

\section{Key Findings:}

1) Single Family Ventilation Case Studies: New energy efficient homes, especially those w/HRV's and advanced leakage control, should require performance based diagnostic blower door testing during construction to insure adeguate tightness.

2) Mulifamily Ventilation Systems,

3) Log home Demonstration, and

4) Single Fannily Heating Systems Not available at this time.

\section{Publications:}

Not available at this time.

\section{Status:}

RCDP Cycle III is planned to be completed by June 30,1992

Contractors Involved:

Washington State Energy Office (WSEO) is Bonneville's contractor. WSEO subcontracts to the state eniergy offices in Oregon, Idaho and Montana.

\section{Project Manager:}

Sheila Bennett

(503)230-3462 


\section{RCDP CYCLE IV}

RCDP Cycle IV consists of two projects: 1)

Pressure Balanced Heating Systems, and 2)

Moisture and Ventilation Investigation in

Retrofitted Manufactured Homes.

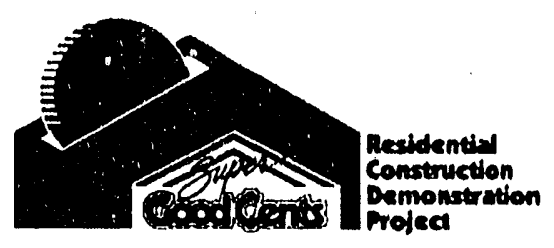

\section{Objective:}

1)This project will te designed to provide information about whether it is warranted to make changes in new residential conservation programs and state code specifications for heating, ventilation, and air conditioning equipment. This project will focus primarily on forced air heating systems and assess alternative heating distribution systems:

a.To quantify the thermal and ventilation effects and associated construction costs of reducing duct leakage and balancing air pressure, design, and installation of forced air heating systems.

b. To demonstrate techniques and technologies that can be used to improve the efficiency of pressure-balance forced air heating systems.

2)This project will investigate the moisture and ventilation levels before and after weatherization and house tightening performed by utilities on existing manufactured homes:

a. To investigate moisture levels and fungal growth on interior surfaces.

b. To examine building air leakage characteristics before and after thermal and tightening measures are performed. c. Determine the appropriateness of the weatherization techniques used as a function of age of home and construction type

\section{Key Findings:}

Not available at this time.

\section{Publication:}

Not available at this time.

\section{Status:}

Work plan development phase January 1991 to April 1992

Implementation phase April 1992 to March 1994.

\section{Contractors Involved:}

Washington State Energy Office (WSEO) is Bonneville's contractor. WSEO subcontracts to the state energy offices in Oregon, Idaho and Montana.

\section{Project Manager:}

Sheila Bennett (503)230-3462 


\section{REFLECTIVE-FOIL INSULATION STUDY}

This project performed tests of the insulation value of reflective foil insulation for comparison with standard bulk type insulation.

\section{Objective:}

The objective of the project was to develop acceptable test and evaluation methods for reflective-foil insulations, produce an initial data base of idealized reflective-foil insulations, test analytical models to predict thermal performance, and to produce a Reflective Insulation Handbook for homeowners and insulation contractors.

\section{Key Findings:}

The current methods of calculating the R-value of reflective-foil insulation work well for single sirspaces, but generally over estimate the R-value of multiple airspace systems. The benefit of multiple irspaces was much less than anticipated.

The R-value of reflective insulations depend upon whether it is used to reduce heat flow horizontally (through walls), upward (through ceilings), or downward (through floors). Therefore, they must be tested for their intended use.

The tested R-value of reflective insulations used in this test, including those with four airspaces, are too low to qualify for most utility residential retrofit weatherization programs in the Pacific Northwest, or any residential energy codes meeting or approaching the Model Conservation Standards. Reflective insulations would have to be combined with other insulations to meet the required minimum $R$-values.
Publication:

Reflective Insulation Handbook DOE/BP-60294 1.

\section{Qther Reference Materials}

Research and Development Data to Define the Thermal Performance of Reflective Materials Used to Conserve Energy in Builıling Applications ORNL/Sub/88/SA 835/1. Iublished by Oak Ridge National Laboratory. Available for $\$ 31.00$ from National Technical Information Services, U.S. Department of Commerce, 5285 Port Royal Road. Springfield, VA 22161.

\section{Status:}

Completed.

\section{Contractors Involved:}

Oak Ridge National Laboratory.

Holometrix, Inc..

\section{Project Manager:}

Rcy Reinhart

(503) 230-5491

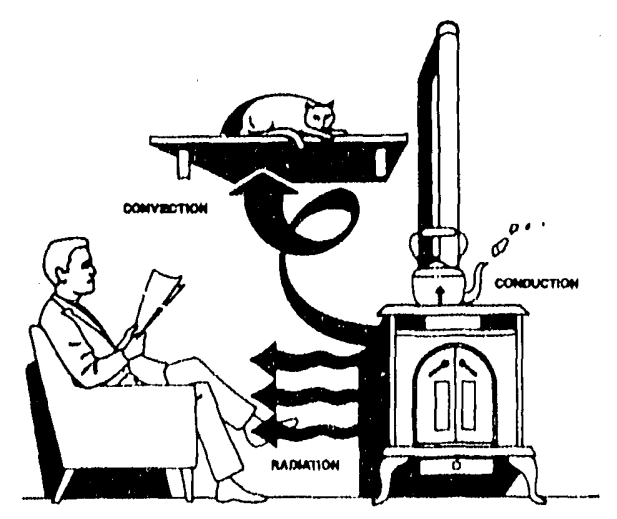




\section{MANUFACTURED HOUSING HEAT LOSS REFERENCE MANUAL}

This manual contains heat-loss coefficients ( $U$ factors) for floors, cellings, walls, and windows for HUD-code manufactured homes and drawings for different construction methods.

\section{Objective:}

To help determine the cost effectiveness of insulation levels in the Super Good Cents (SGC) program for HUD-code manufactured homes and to help mariufacturers find the best ways to build and insulate walls, ceilings, and floors.

\section{Key Findings:}

Calculated heat-loss coefficients (U-factors) are provided for common installation and construction methods used in manufactured homes.

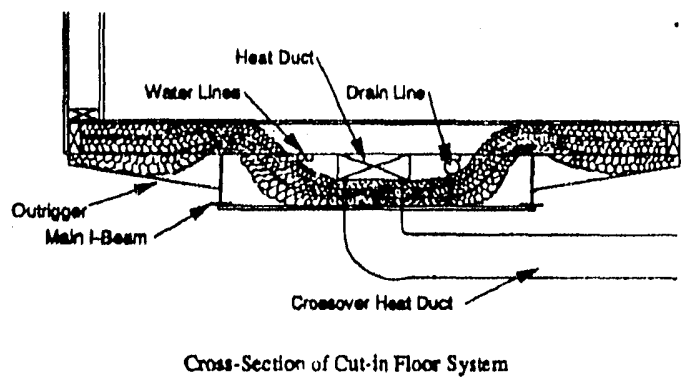

Publication:

Super Good Cents Heat Loss Reference Manual:Manufactured Homes Heat loss Assumptions and Calculations DOE/BP-35738-3 March 1990

\section{Status:}

Completed

Contractors Involved:

Ecotope

\section{Project Manager:}

Steve Onisko

(503) $230-54 ? 50$

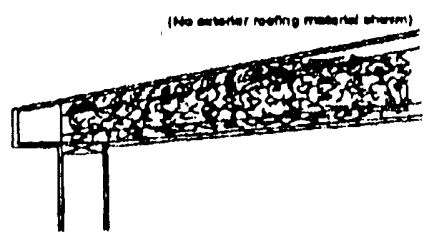

Blown Vaulted Colling With Cable Vents

Wall Corner Type

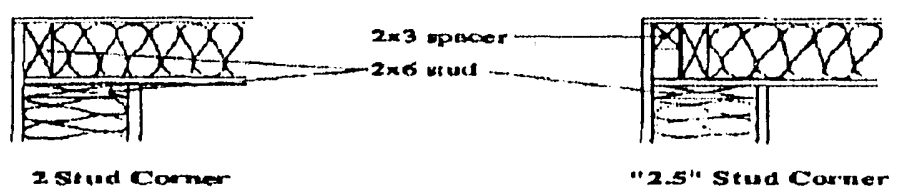




\section{TECHNICAL INFORMATION TRANSFER}

To provide accurate technical information aimed at conservation in the manufactured housing sector.

\section{Objective:}

Bonneville's technical and marketing programs have developed a !arge reservoir of information and expertise that exist no where else in the nation. This effort is designed to disseminate both technical and program information to a larger audience beyond the pacific northwest.
Key Findings:

Ongoing.

Publication:

None at this time.

Status:

Ongoing

Project Manager:

Steve Onisko

(50.3) 230-5490 


\section{VENTILATION RESEARCH CONSORTIUM}

The Ventilation Research Consortium (VRC) was established to fund projects which improve our understanding of how to economically achieve adequate ventilation with minimal energy penalties. To achieve this goal, the consortium has funded studies that explore the interactions between natural and mechanical ventilation and projects to improve ventilation controls.

\section{Objective:}

To develop a consortium of organizations willing to cofund research projects in residential ventilation. The consortium funds projects which will ultimately lead to improved ventilation systems and controls. The first effort of the consortium was to sponsor an Electric Power Research Institute workshop on ventilation which helped define research needs. The first project sponsored by VRC was a multi-tracer gas study of infiltration and mechanical ventilation in singlefamily houses. This effort resulted in useful and simple models that predict overall ventilation rates. Projects to evaluate ventilation in multifamily structures is being planned.

\section{Key Findings:}

As a result of the first single family ventilation project, which involved 10 sites, it has been established that when natural infiltration is at least twice as large as mechanical ventilation, the exhausted is one half induced ventilation, and one half displaced infiltration. This rule serves well for most situations commonly encountered in houses. Field work also shows that differential pressurization, caused by closing doors between supples and returns of forced air heating systems, can more than double the infiltration rate in a house.

Publication:

Modeled and Measured Infiltration

EPRI CU-7327

\section{Status:}

Field work has been completed on 10 single family houses. Preliminary designs for new ventilation controls are being developed, and work on inulti. family structures will be performed in early 1992.

Contractors Involved:

Lawrence Berkeley Laboratories - Max Sherman EPRI - John Kesselring ECOTOPE - Larry Palmiter

\section{Project Manager:}

Mark Jackson

(503)230-5475

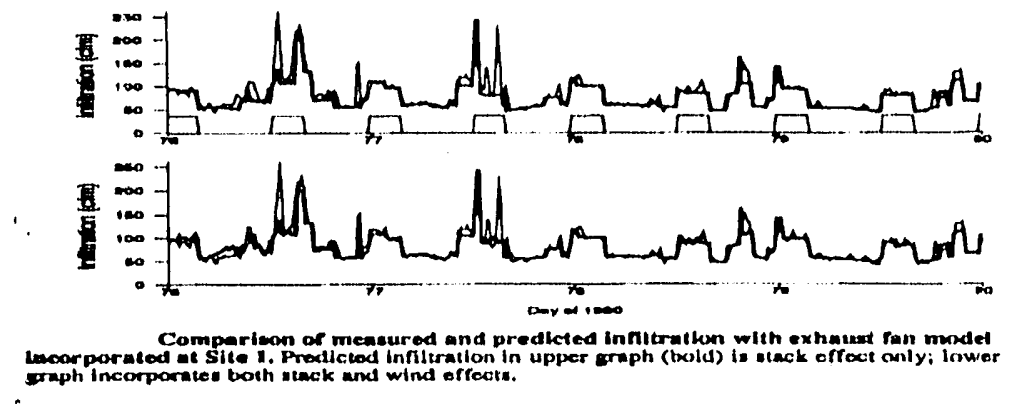




\section{INFLUENCE OF SUBSLAB AGGREGATE PERMEABILITY ON SUBSLAB VENTILATION PERFORMANCE}

The purpose of the project is to determine the influence of subslab gravel size on the performance of subslab ventilation systems installed for radon mitigation.

\section{Objective:}

To provide technical basis upon which program policy is based regarding mitigation of MCS homes.

\section{Key Findings:}

Requirement of clean course gravel beneath concrete slabs in new construction was substantiated. Higher permeable soils require higher permeable gravel for equivalent performance.
Publication:

Technical Report is currently in Printing Process.

\section{Status:}

Completed, October 31, 1991.

Contractors Involved:

Lawrence Berkeley Laboratory.

Washington Energy Extension Service.

Project Manager:

Charles Eastwood

(503)230-4992

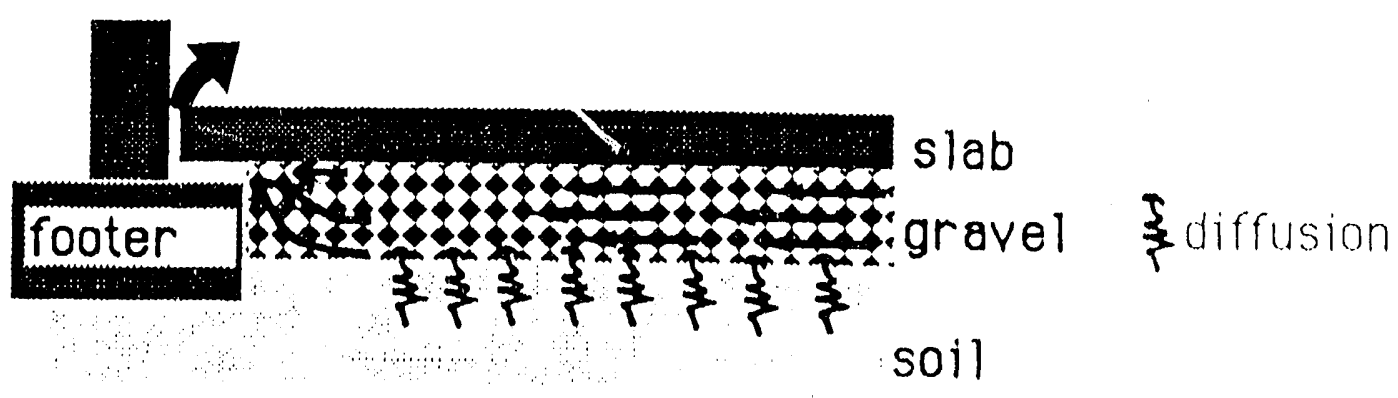




\section{WATER HEATER BIOMITIGATION STUDIES}

An EPRI tailored collaboration project to study methods of reducing or eliminating undesirable microorganism growth in domestic water systems.

\section{Objective:}

To identify effective mitigation measures for reducing or eliminating concentrations of undesirable microorganisms in residential water heaters.

Key Findings:

Not Avallable at this time.

\section{Publication:}

Not Available at this time.

\section{Status:}

Project not started yet.

Contractors Involved:

Dr. Carl Hiller, University of Pennsylvania.

\section{Project Manager:}

Charles Eastwood

(503) 230-4992.

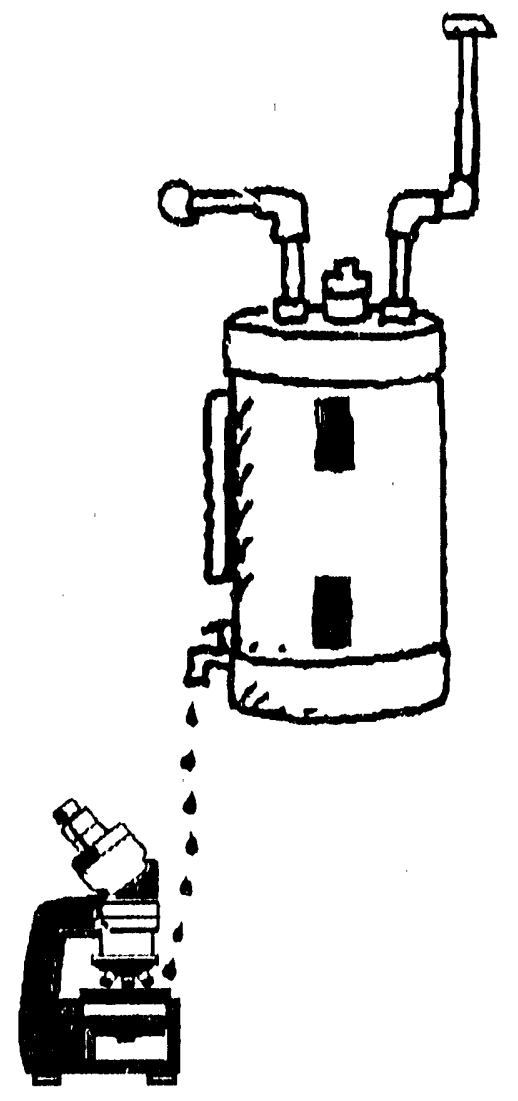




\section{APPENDIX A - INDEX OF PUBLICATIONS}

The following is a list of publications from past projects. These reports are obtainable by contacting the Residential Technology Section secretary at (503)230-5488.

An Analysls of Predicted U.S. Monltored Space Heat Energy Use in 120 Homes. DOE/BP-1787 (February 1992)

Appliance Analysis

DOE/BP-23821-8 (January 1992)

Airleakage control Manual

DOE/BP-1687 (January 1992)

Active Ventilation Report

DOE/BP-23821-7 (April 1991)

Infiltration and Ventilation In New Electrically Heated homes in the pacific

Northwest. - RCDP Cycle II. DOE/BP-23821-6 (February 1991)

Sensible living for the 90's A Portfollo of Case Studles from RCDP Cycle 1 DOE/BP-23821.4 (September 1990)

Reflective Insulation Handbook. DOE/BP-60294-1 (August 1990)

Construction Cost Analysis for the Residential Construction Demonstration

Project - Cycle II. DOE/BP 1417 (June 1990)

Vacuum Window Glazings for Energy Efficlent Building - Summary Report DOE/BP-64357-2 (May 1990)

Manufactured Homes Simulated Thermal Analysis an Cost Effectlveness Study DOE/BP-35738-2 (May 1990)

RCDP Cycle I Bullder Exit Survey. $\quad$ DOE/BP-1414 (May 1990)

Data Logger Analysis Case Studies - RCDP Cycle I.

DOE/BP-23821-5 (May 1990)

Heat Pump Buyers Guide DOE/BP01311 (March 1990) 
Operating and Maintaining Your Heat Pump (March 1990)

Ventilation Measurement Energy Efficient Multi-family Dwelling Units in the Paclfic Northwest. LOE-BP.64352-1 (March 1990)

The Northwest Wall Molsture Study: A Field Study of Excess Moisture In Walls and Moisture Problem and Damage in New Northwest homes.

DOE/BP-91489-1 (March 1990)

The Northwest Wall Moisture Study: A Field Study of excess moisture in walls and Molsture problems and Damage in New Northwest Energy-Efficlent Homes. PSU (February 1990)

Japanese Refrigerator: A fleld Performance Analysis - Final Report DOE/BP-95951-2 (February 1990)

Thermal Analysis Results for the Residential Construction Demonstration Project DOE/BP-1360 (February 1990)

Cost Data for Manufactured Homes in RCDP - Appendices DOE/BP-13795-25 (January 1990)

Case study of Regional Manufacturers Participating in the Manufactured Housing RCDP. DOE/BP-13795-23 (January 1990)

Dealer Participation in BPA's Manufactured Housing Residential Construction Demonstration Project. DOE/BP-1324 (Deccmber 1989)

An Analysis of Predicted Versus Monitored Space Heat Energy Use in 83 Homes DOE/BP-23821-3 (December 1989)

Northwest Residential Infiltration Study - Volume I: Analysis and Results. DOE/BP-34625-1 (November 1989)

Japanese Refrigerator: A Field Performance Analysis - Field Data Inspection, Screening and Compilation. DOE/BP-95951-3 (November 1989)

Modular Housing Case Study

DOE/BP-23821-2 (October 1989)

A Superwindow Field Demonstrator Program in Northwest Montana Phase II DOE/BP-63401-2 (September 1989) 
Northwest Residential Radon Standards

Volume I Project Report. DOE/BP-1273 (September 1989)

Northwest Residential Radon Standards

Volume II Comment Letters. DOE/BP-1274 (September 1989)

Estimation of Radon Potential in the Pacific Northwest Using Geological Data DOE/BP-1234 (June 1989)

Heat Pump Water Heater in Multi-Family Housing Test

DOE/BP-62314-1 (April 1989)

Japanese Refrigerator Field Testing

DOE/BP-1217 (March 1989)

Prediction of Moisture in the Walls of Residences

DOE/BP-64355-1 (March 1989)

Japanese Refrigerator: A Field Analysis - Summary Report

DOE/BP-95951-1 (February 1989)

Residential Water Heating Qualification Level Analysis

DOE/BP 34623-1 (February 1989)

A Comparison of Indoor Air Quality in Conservation and Model Conservation Standards New Homes in Pacific Northwest

DOE/BP-12921-1 (September 1988)

Field Performance of an Energy Efficient Refrigerator Over 29-months DOE/BP-1115 (September 1988)

Recruiting Volume Builders into Super Good Cents - Final Report DOE/BPO23821-1 (August 1988)

Construction Cost Analysis for the Residential Construction Demonstration Project - Cycle I. DOE/BP 1031 (July 1988)

Radon 3-Month/12-Month Field Study

DOE/BP-1218 (July 1988)

Heating New Homes - A comparison of the Cost of Heating with Electric, Natural Gas an Fuel Oil Heating Systems (NWPPC). (June 1988) 
A Study of Filling of Wall Cavities with Retrofit Wall Insulation DOE/BP.1017 (June 1988)

Fan Pressurization Test Results

DOE/BP-1236 (May 1988)

Estimation of Total Ventilation Rates for Proposed Ventilation Strategies in New Residential Structures. DOE-BP-998 (May 1988)

RSDP - Executive Summaries. DOE/BP-983 (April 1988)

Final Report - Control Homes Characteristics In the RSDP Program (\#1). DOE/BP-990 (April 1988)

Final Formaldehyde Testing Results for the RSDP Program (\#12) DOE/BP-993 (March 1988)

Field Moritoring of Wintertime Performance of a Residential Dehumidifier DOE/BP-981 (March 1988)

Pacific Northwest Existing Homes Indoor Air Quality Survey and Weatherization Sensitivity Study. DOE/BP-12921-2 (February 1988)

The Incidence of Moisture, Decay and Insect Infestation in Residential Crawlspace. DOE/BP-13795-19 (December 1987)

Radon and Remedial Action in Spokane River Valley Homes DOE/BP-12921-3 (December 1987)

Preliminary Radon Testing Results for RSDP (\#10) DOE/BP-976 (October 1987)

Two Studies of the Effects of Small Exhaust Fans on Indoor Air Quality DOE-BP-13655-1 (July 1987)

Model Conservation Standards - City of Tacoma Construction Cost Evaluation. DOE/BP-31011-1 (June 1987)

Energy Use Test Procedures for Appliances - Case Study of Japanese Refrigerators DOE/BP-63585-1 (May 1987) 
Residential Standards Demonstration Program - Solar Access Report. DOE/BP-1098 (December 1986)

Model Conservation Standards - Cost Effectiveness Analysis Technical Appendices. (December 1986)

RSDP Thermal Performance Program Results (\#3).

DOE/BP-13795 (October 1986)

Residential Standards Deınonstration Program - Occupant Survey Analysis (\#9). DOE/BP-13795-17 (October 1986)

RSDP Thermal Performance Program Results (\#7).

DOE/BP-13795-18 (September 1986)

Residential Standards Demonstration Program - Builder Cost Analysis (\#5). DOE/BP-20521-1 (May 1986)

Residential Standards Demonstration Program - Builder Exit Survey (\#6) DOE/BP-676 (March 1986)

Residential Standards Demonstration Program - Occupants are they Unique? (\#4). DOE/BP-633 (February 1986)

RSDP Preliminary Air to Air Heat Exchangers Testing (\#2) DOE/BP-582 (January 1986)

The Spokane Wall Insulation Project: A Field Study of Moisture Damage in Walls insulated without a vapor barrier. PSU (April 1984)

The Effects of External Insulation on Electric Water Heaters DOE/BP-94 (February 1982)

A Field Study of Moisture Damage in Walls Insulated without a Vapor Barrier ODE (November 1979)

Manufactured Homes Cost Data Analysis Report DOE/BP 35738-1

Construction Cost Analysis for the Residential Construction Demonstration Project - Cycle I. DOE/BP-1031 
Oregon Building Code Compliance Study.

DOE/BP-2095-1

Cost Data Collection for Manufactured Homes in RCDP

DOE/BP-13795-24

Phase I - High-R Window 'rechnology Development

DOE/BP-63401-1

Strategy of Establishing an Energy Efficient Water Heating Programs for the Residential Sector - DRAFT DOE/BP-1368

Exhaust-Air Heat Pump Study - Experimental Results \& Update of Regional Assessment for the Pacific Northwest. DOE/BP-60326-1

Northwest Residential Infiltration Study - Volume 2: Sample Selection an Bias Assessment. DOE/BP-34625-2

Exhaust-Air Heat Pump Study: Experimental Results and Update of Regional Assessment for the Pacific Northwest.

Findings on Model Conservation Standards Cost Effectiveness and Consumer Economic Feasibility.

Thermal Analysis Results for the Residential Construction Demonstration Project. 

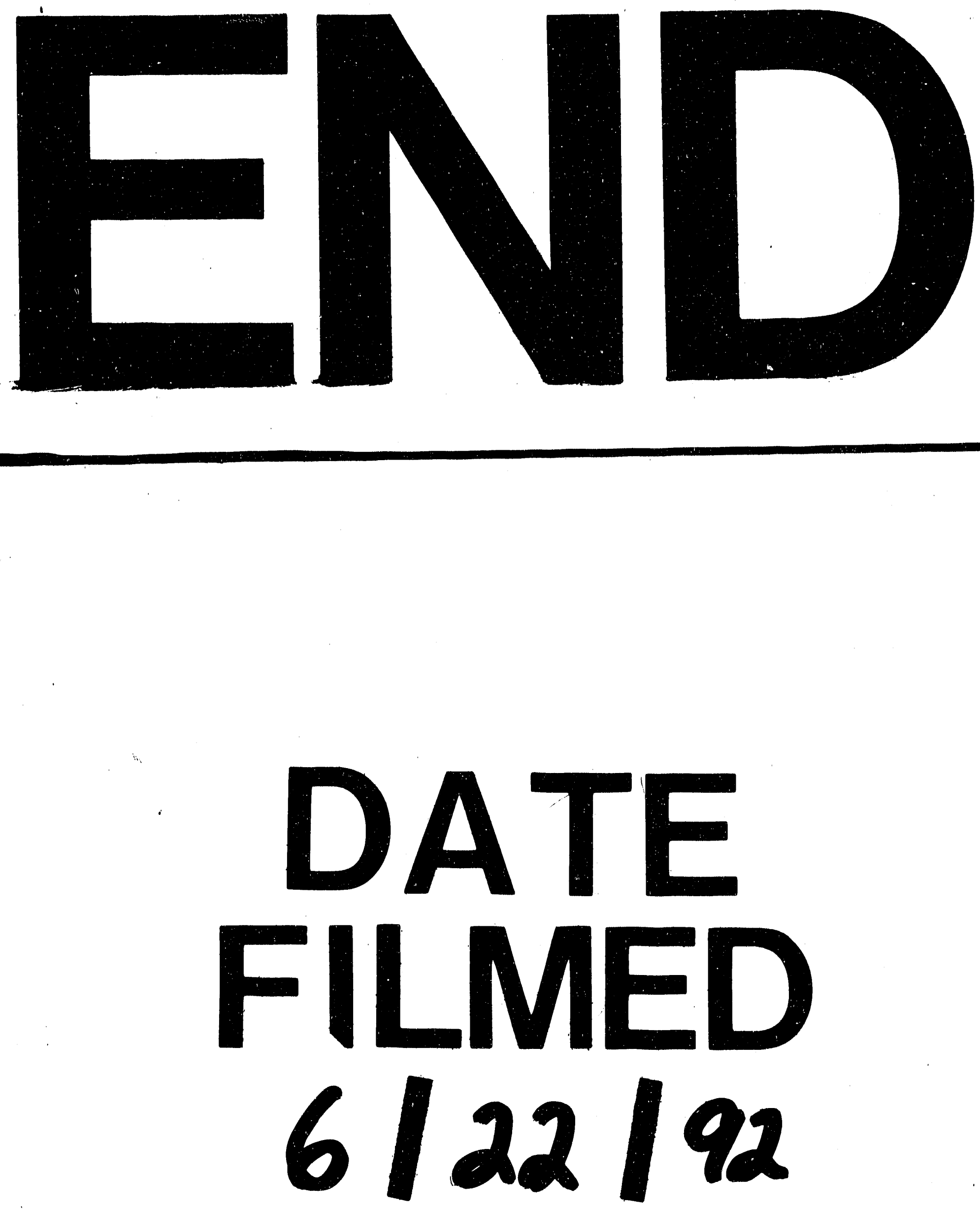
